\title{
$\beta$ 遮断薬による心臟突然死の予防
}

池田隆徳

$\beta$ 遮断薬は, $\mathrm{Na}^{+}$あいは $\mathrm{K}^{+}$チャネル遮断作用を有する狭義の抗不整脈薬に比べて, 不整脈に対す る作用効果は弱い. しかし, 交感神経活動の緊張緩和や頻拍時の心拍数減少などの二次的な効果を有す るため, 不整脈治療に使用される頻度は高い。 また, 狭義の抗不整脈薬は強力な不整脈抑制作用を有す る反面，心収縮力低下や危険性の高いほかの不整脈を惹起することがあり，この点においても $\beta$ 遮断薬 は重篤な副作用の発現が比較的少なく, 使用しやすい薬物といえる. さらに不整脈領域では, 持続性心 房細動・心房粗動のレートコントロール目的での使用頻度が最も高く, 交感神経緊張が関与する心室不 整脈の抑制や予防，心不全や心筋梗塞患者の心臓突然死の予防目的でも広く用いられている. $\beta$ 遮断薬 には経口薬のみならず静注薬もあり，急性期の心室不整脈の管理においてなくてはならない薬物となつ ている. 心室不整脈の薬物治療の中心は亚群抗不整脈薬であるが, それが無効である症例に対しては, $\beta$ 遮断薬が有効であることが多い.

(心電図, $2016 ; 36: 64 ＼mathrm{~ 73) ~}$

\section{I . はじめに}

心臓突然死の多くは, 心室細動や心室頻拍などの 致死性心室不整脈により生じる。そのため, 心蔵突 然死を予防するには，これらの不整脈を抑制するよ りほかはない，心室不整脈の抑制には，主にアミオ ダロンやニフェカラントのような III 群抗不整脈薬が 使用されるが，ガイドラインでは $\beta$ 遮断薬も有用で

\begin{tabular}{|ll|}
\hline Keywords & $\bullet \beta$ 遮断薬 \\
& ・ 臟突然死 \\
& ・抗不整脈作用 \\
& - 自律神経 \\
\hline
\end{tabular}

東邦大学医学部内科学講座循環器内科学分野

（１43-8541＼cjkstart東京都大田区大森西 6-11-1）
あるとされており，その有用性を示すエビデンスも 数多く報告されている.

本稿では，まず不整脈治療において使用する場合 の $\beta$ 遮断薬の作用機転と期待される薬理作用につい て, 次いでこれまでの臨床研究の結果を交えなが ら，心室不整脈の管理と心臟突然死の予防における $\beta$ 遮断薬の選択基準や使い方について概説する.

\section{II. $\beta$ 遮断薬の電気生理学的作用機転}

心臓における交感神経の活性化は, 不整脈の発現 や心不全の悪化をもたらすことが知られている(図 1). 交感神経が活性化すると, 交感神経終末から遊離す るノルアドレナリンが各領域の心筋細胞の $\beta$ 受容体 に結合する。これにより，細胞内の $\mathrm{G}$ タンパクお

Prevention of Sudden Cardiac Death Using $\beta$-Blockers Takanori Ikeda 


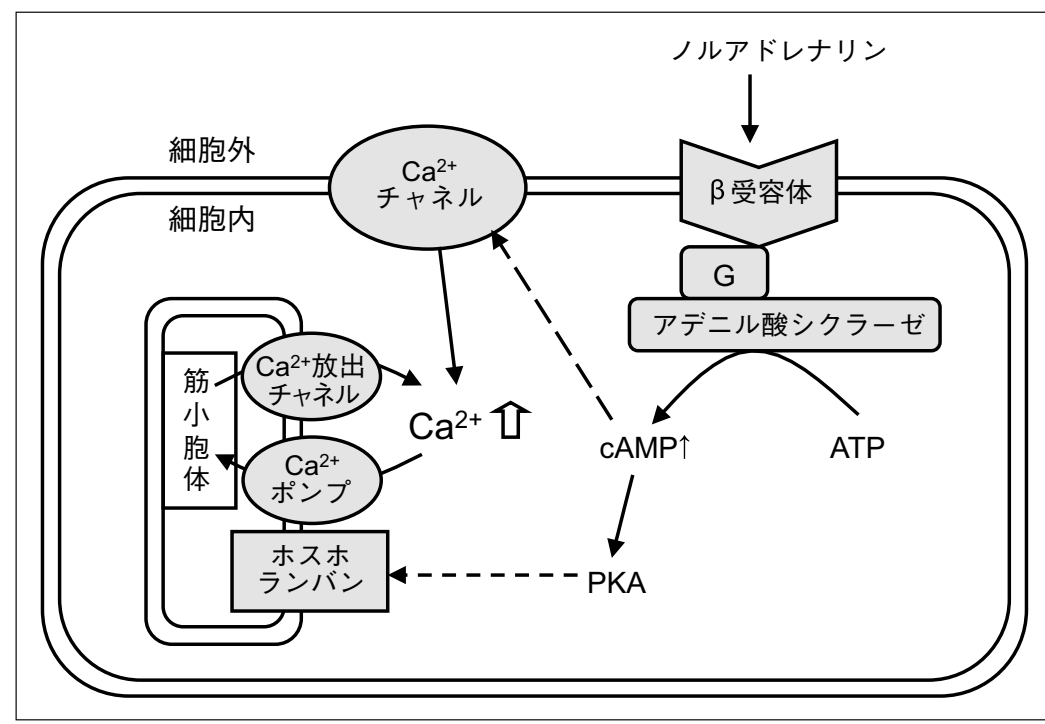

図 1

交感神経活性化による細胞レベルでの受 容体を介した作用機転

$\mathrm{G}: \mathrm{G}$ タンパク, $\mathrm{PKA}$ ：プロテインキナーゼ $\mathrm{A}$

よびアデニル酸シクラーゼが活性化され，環状アデ ノシンーリン酸 (cyclic adenosine monophosphate: cAMP) 濃度が上昇する。cAMPはリン酸化酵素の 活性化を介して, $\mathrm{Ca}^{2+}$ チャネルからの $\mathrm{Ca}^{2+}$ の流入 を増大させるとともに，筋小胞体の機能を向上さ せ, 心収縮力の増強と心拍数の上昇に寄与する ${ }^{1)}$. 心収縮力の増強と心拍数の上昇は, 心筋を疲弊させ る重要な要因であるため, その結果として不整脈の 発現や心不全の悪化を助長することになる。 $\beta$ 遮断 薬を投与した場合，このカスケードが遮断されるた め, 心不全や不整脈の改善につながると考えられる.

このような細胞レベルでの受容体を介した作用機 転とは別に， $\beta$ 遮断薬は心房あるいは心室筋細胞に 対して間接的に作用することが知られている。 $\beta$ 遮 断薬によって洞結節と房室結節の伝導が抑制される と, 心筋の活動電位持続時間 (action potential duration：APD)が延長する．APDの短縮は不整脈 の持続に関与するリエントリーの重要な成立要因で あるため, $\beta$ 遮断薬で APD を延長させれば, リエ ントリーの成立が困難となり，ひいては持続性不整 脈の抑制につながると考えられる.

\section{III. 不整脈治療において期待される作用}

$\beta$ 遮断薬は本来， $\beta$ 受容体を遮断することによっ て交感神経活動を低下させ，薬理学的効果を発揮す る薬物である。しかし近年， $\beta$ 遮断薬は様々な作用 を併せもつことが知られるようになり，不整脈の抑 制あるいは心臓突然死の予防においても使用されて いる.

表 1 に示すように， $\beta$ 遮断薬は様々な作用を有す るが, 不整脈治療においては, (1) $\beta$ 受容体遮断作用 の強度, (2)心臟 $\left(\beta_{1}\right)$ 選択性, (3)内因性交感神経刺 激作用 (intrinsic sympathomimetic activity: ISA) の有無，が重視される ${ }^{2)}$. 心機能低下 (心不全合併) 患者では, 脂溶性の有無も重要な要因となる。脂溶 性の薬片は, 心保護作用 (生命予後の改善)効果を期 待することができる．以前，重要視された $\mathrm{Na}^{+}$ある いは $\mathrm{K}^{+}$チャネル遮断による膜安定化作用 (membrane stabilizing activity：MSA)は, 通常の使用量では 発現しないため, 現在では考慮されなくなっている.

不整脈治療には， $\beta$ 受容体遮断作用が強く， $\beta_{1}$ 選択性が高く, ISAがない薬剤が理想的である。い うまでもなく， $\beta$ 受容体に対する遮断力が高けれ ば，それだけ交感神経活動の緊張緩和が期待でき 
る。しかし，これを左右するのが ISAの有無であ り, ISAが存在すると, 心拍数の調節や不整脈の抑 制に対する効果は期待できない. $\beta$ 遮断薬を投与す ると, 心拍数の減少と心収縮の抑制が生じるが， $\beta_{1}$ 受容体の選択性が高い薬剤ほど，心拍数減少が心収

表 $1 \beta$ 遮断薬で考慮される薬理作用

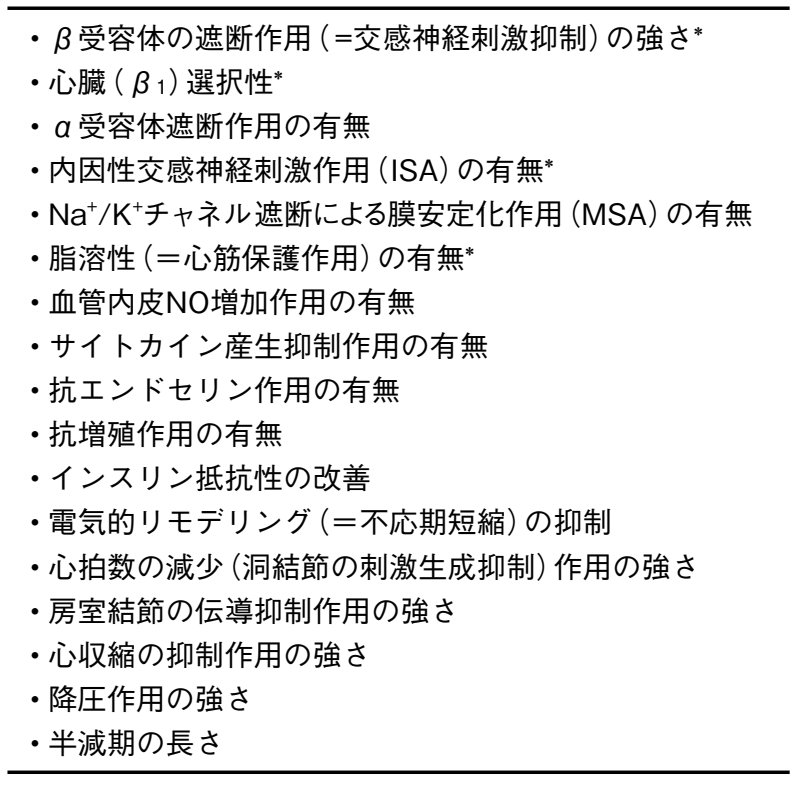

*: 不整脈治療において重視される作用
縮抑制よりも強く現れる傾向にある。そのため, 頻 脈性不整脈の治療については, 心臓 $\left(\beta_{1}\right)$ 選択性も ISA と同等に重要な要因となる.

\section{IV．心臓突然死予防における $\beta$ 遮断薬の位置づけ}

近年に発刊された欧州心臓病学会のガイドライ ン ${ }^{3)}$, あるいは過去の米国心臟協会／米国心臓病学 会/欧州心臓病学会のガイドライン ${ }^{4)}$ 見ても, 心 室不整脈の管理および心臓突然死の予防における $\beta$ 遮断薬の位置づけは高いことがわかる．薬物として 推奨されているのは $\beta$ 遮断薬と III 群抗不整脈薬のみ であり, しかも $\beta$ 遮断薬は而群抗不整脈薬よりも優 先順位が高くなっている，その理由を図2に示した.

持続する心室不整脈(持続性心室頻拍，心室細動) のメカニズムは，主に旋回興奮(リエントリー)であ る.このリエントリーを抑制するには, $\mathrm{K}^{+}$チャネ 儿遮断作用 (不応期の延長作用)を中心とした III 群抗 不整脈薬が適する。そのため，ガイドラインでは III 群抗不整脈薬を優先的に推奨しているように感じら れる。しかし，リエントリーが成立するには，トリ ガーとなる局所からの巣状興奮(心室期外収縮, 非 持続性心室頻拍)の存在が必要である. 局所巣状興 奮のメカニズムは，主に異常自動能(もしくはトリ

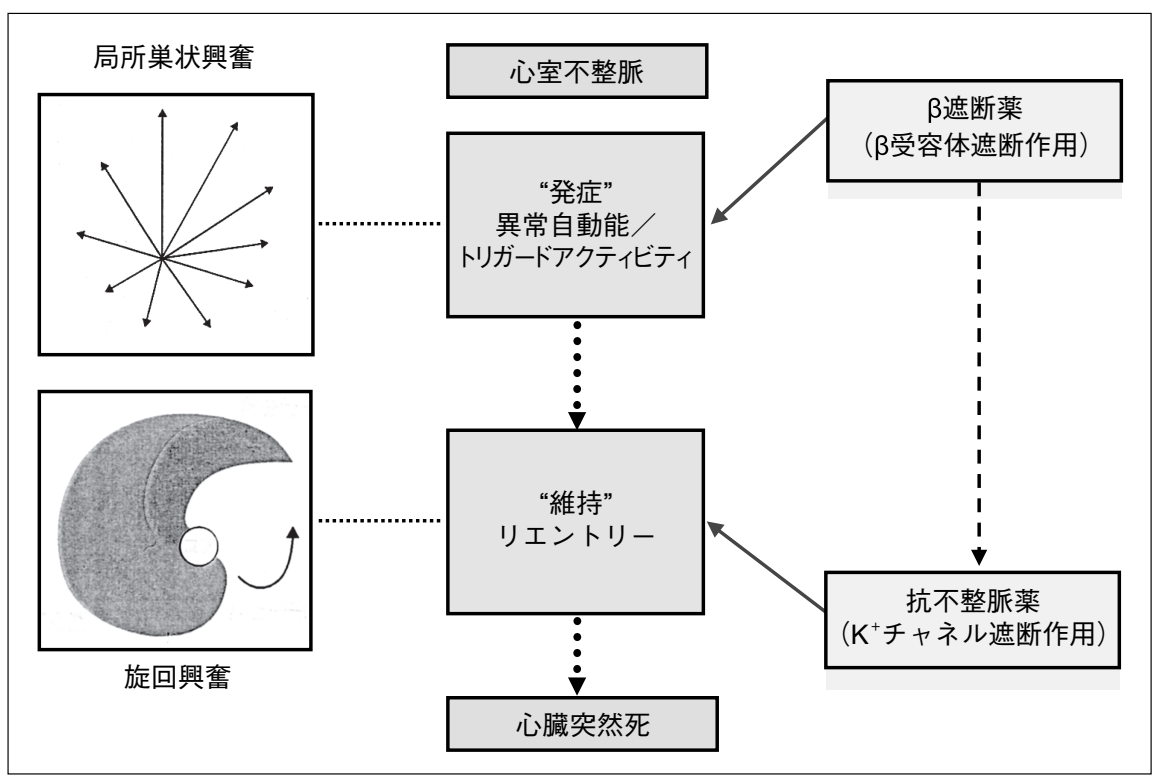

図 2

心臓突然死の予防において $\beta$ 遮断 薬を重視する理由 


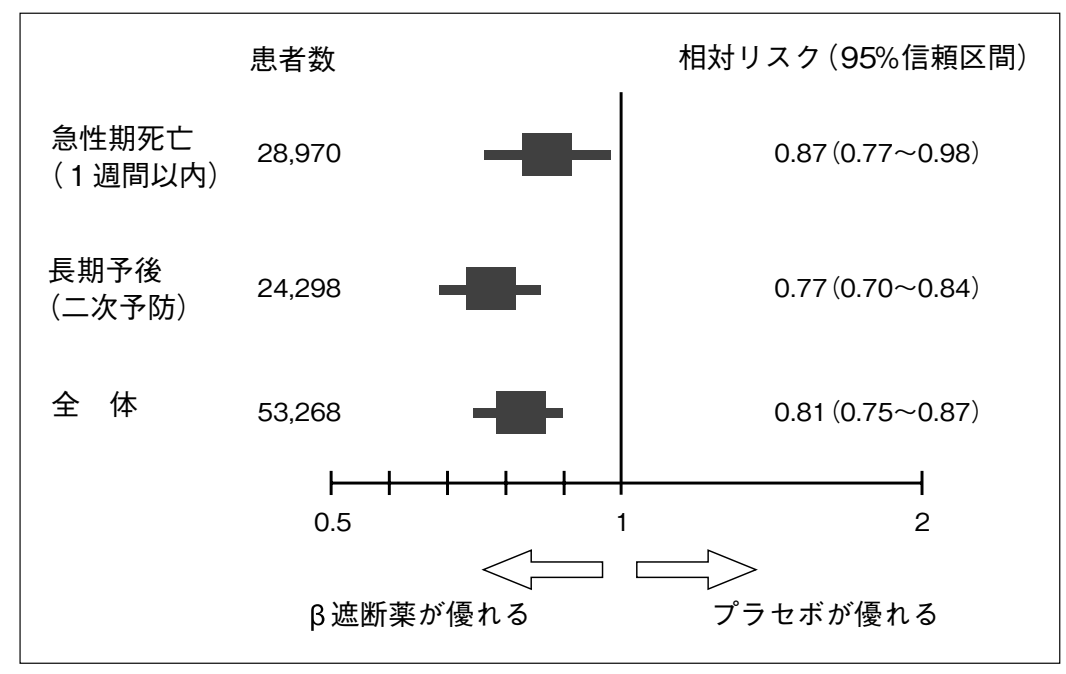

図 3

心筋梗塞後患者における $\beta$ 遮断薬群とプ ラセボ群の予後改善効果を比較したメタ 解析

心筋梗塞発症早期に $\beta$ 遮断薬を導入すると, 急 性期あるいは長期 (慢性期)の予後改善効果が得 られる。

〔文献 5)より引用改変〕

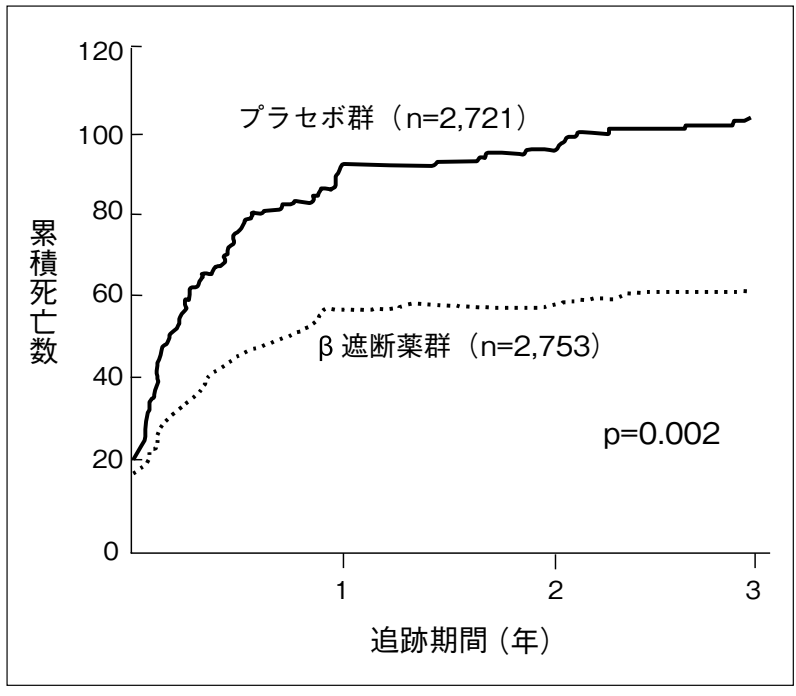

図 4 心筋梗塞後患者における $\beta$ 遮断薬群とプラセ ボ群の突然死予防効果を比較した $5 つ の$ 臨床 試験のメ夕解析

$\beta$ 遮断薬群のほうがプラセボ群よりも突然死の発現率を減少 させる。

〔文献 6)より引用改変〕

ガードアクティビティ)であるため，これらを抑制 することが，ひいてはリエントリーの成立の抑制に つながる. 異常自動能を抑制する薬物は, いうまで もなく $\beta$ 遮断薬である. 欧米のガイドラインではこ のような考え方にしたがって，まずは $\beta$ 遮断薬を考 慮し，次に群抗不整脈薬を推奨するような内容に なっている.

\section{$V . \beta$ 遮断薬の心臓突然死予防におけるエビデンス}

心筋梗塞後, あるいは心不全患者の突然死予防効 果における $\beta$ 遮断薬の位置づけは高い。これまで多 くの臨床試験によって，そのエビデンスは確立され

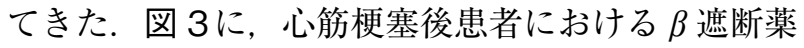
とプラセボの予後改善効果を比較したメ夕解析の結 果を示す ${ }^{5)}$. 心筋梗塞発症早期に $\beta$ 遮断薬を導入す ると, 急性期あるいは長期 (慢性期)の予後改善効果 が得られることが示されている. 図 4 は心筋梗塞後 患者の突然死予防における $\beta$ 遮断薬 (メトプロロー ル）の効果を検証した，5つの二重盲検比較試験の メ夕解析の結果である ${ }^{6)}$. 心筋梗塞後患者全 5,474 例を $\beta$ 遮断薬群とプラセボ群に分類して評価したと ころ， $\beta$ 遮断薬群のほうが突然死の発現率を有意に 減少 $(-42 \%)$ させた。図 5 に心不全患者の突然死 予防に扮ける効果を $\beta$ 遮断薬群(メトプロロールま たはビソプロロール) とプラセボ群で比較した, 2 つの臨床試験(MERIT-HF および CIBIS II )のサブ 解析の結果を示す ${ }^{7)}{ }^{8}$. 両試験とも， $\beta$ 遮断薬群 はプラセボ群と比べて突然死の発現を有意に減少さ せており，その減少率はメトプロロールでは42\%，ビソプロロールではー44\%であった。

Optimal Pharmacological Therapy in Cardioverter Defibrillator Patients (OPTIC) は, 植込み型除細動 


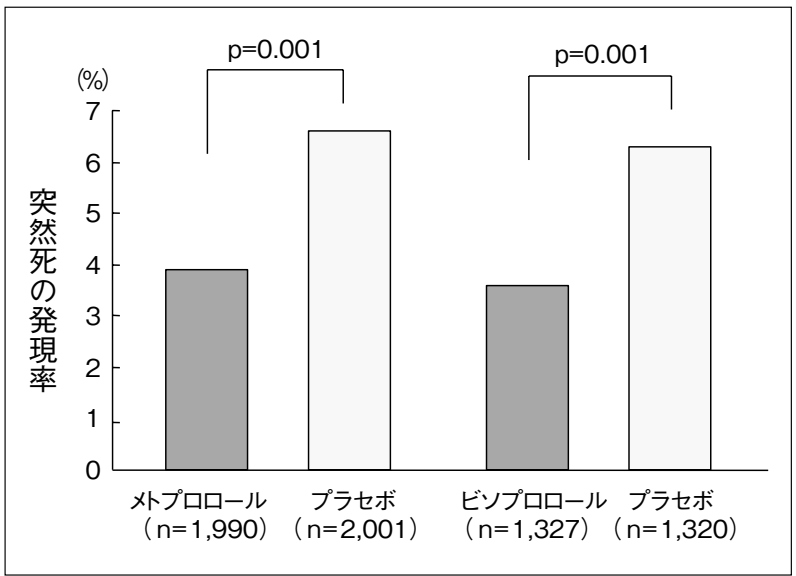

図 5 心不全患者における $\beta$ 遮断薬群とプラセボ群

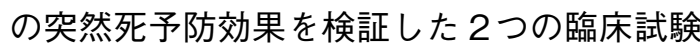
のサブ解析

MERIT-HF 試験(左) と CIBIS II 試験(右)ともに, $\beta$ 遮断薬 群はプラセボ群と比較して, 突然死の発現率が低い.

[文献 7)，8）上り引用改変〕

器 (implantable cardioverter defibrillator : ICD) 植込み患者において， $\beta$ 遮断薬，ソタロール，アミ オダロン $+\beta$ 遮断薬の 3 薬間で ICD 作動率減少効 果を検証した臨床試験である $(\text { 図 6 })^{9)}$ 。 よく知られ たことではあるが，ソタロールは $\beta$ 遮断薬として分 類されることもあれば，抗不整脈薬として分類され ることもある薬片である。また，アミオダロンの抗 不整脈効果はソタロールよりも高いが， $\beta$ 受容体遮 断作用はソタロールよりも明らかに弱いことも周知 の通りである，先に述べたように，欧米では心室不 整脈の抑制において $\beta$ 遮断作用 ( $\beta$ 遮断薬)を重視し ているため, OPTICにより $\beta$ 遮断薬に抗不整脈薬 を付加すると，さらに心室不整脈が抑制されるか否 かを検証した。結果としては，アミオダロン $+\beta$ 遮 断薬, ソタロール, $\beta$ 遮断薬の順で ICD 作動の減 少効果があること， $\beta$ 遮断作用に抗不整脈作用を付 加すると ICD作動が減少することが示された.

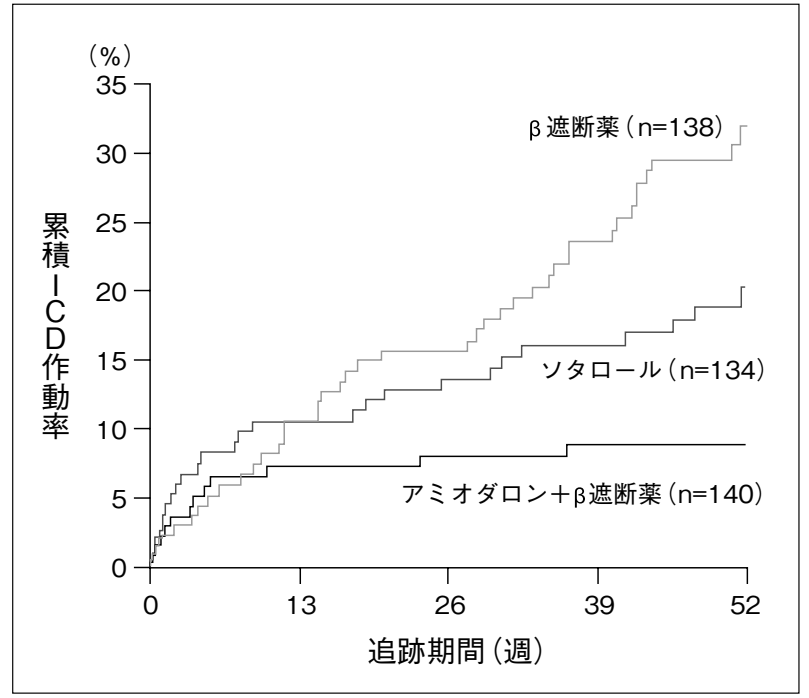

図 6 ICDが植込まれた患者における $\beta$ 遮断薬を中 心とした薬剤のICD作動率を比較した OPTIC 試験

$\beta$ 遮断作用に抗不整脈作用を付加すると, ICD 作動が減少 する。

〔文献9）より引用改変〕

\section{VI. 不整脈治療に適した $\beta$ 遮断薬と選択基準}

$\beta$ 遮断薬(経口)には多くの種類がある(表 2)が, これらで不整脈治療に用いられることが多いのは, ビソプロロール，カルベジロール，メトプロロール， プロプラノロールである(心不全を合併した不整脈 患者であれば，ビソプロロールとカルベジロールの みが保険適応)。これら以外の $\beta$ 遮断薬は, 主に降 圧目的で使用されており，不整脈をターゲットとし て用いられることは少ない。近年，水溶性の高い $\beta$ 遮断薬(アテノロールなど) は，心不全患者に使用で きず，予後改善効果も期待できないことから，使用 頻度が減少している.

特定疾患に限定せず，世界市場において使用頻度 の高い $\beta$ 遮断薬といえばカルベジロールとビソプロ ロールで，この2剂の薬理作用は両極端である。 カ ルベジロールは心臓 $\left(\beta_{1}\right)$ 以外にも $\beta_{2}$ や $\alpha$ 受容体に 対する作用，さらには多くの付随的な作用を有して いる薬剤であるため,「マルチ $\beta$ 遮断薬」，ビソプロ ロールは心蔵に対する $\beta$ 遮断作用のみを有している 
表 2 不整脈治療に用いる上で考慮すべき経口 $\beta$ 遮断薬の薬理作用の違い

\begin{tabular}{|c|c|c|c|c|c|c|}
\hline$\beta$ 遮断薬 & $\begin{array}{c}\beta \text { 遮断カ } \\
(\text { プロプラノロール =1.0) }\end{array}$ & $\beta 1$ 選択性 & ISA & 脂溶性 & 作用時間 (時) & 付加的作用 \\
\hline アロチノロール & $<0.1$ & - & - & $?$ & $9 \sim 11$ & $a$ 遮断 \\
\hline アセブトロール & 0.3 & 0 & () & 0 & $6 \sim 7$ & \\
\hline ラベタロール & 0.3 & - & - & - & $3 \sim 4$ & $a$ 遮断 \\
\hline ソタロール & 0.3 & - & - & - & $8 \sim 10$ & $\mathrm{~K}^{+}$チャネル遮断 \\
\hline プロプラノロール & 1.0 & - & - & (0) & $3 \sim 4$ & \\
\hline ナドロール & 1.0 & - & - & - & $12 \sim 24$ & \\
\hline アテノロール & 1.0 & 0 & - & - & $8 \sim 10$ & \\
\hline メトプロロール & 1.0 & 0 & - & 0 & $3 \sim 4$ & \\
\hline ベタキソロール & 4.0 & 0 & - & $\bigcirc$ & $12 \sim 18$ & \\
\hline ピンドロール & 6.0 & - & (2) & $\bigcirc$ & $3 \sim 4$ & \\
\hline セリプロロール & 9.4 & 0 & $\bigcirc$ & $?$ & $4 \sim 6$ & \\
\hline カルテオロール & 10.0 & - & $\bigcirc$ & $?$ & $4 \sim 6$ & \\
\hline カルベジロール & 10.0 & - & - & () & $7 \sim 9$ & $a$ 遮断+多数 \\
\hline ビソプロロール & 10.3 & () & - & 0 & $8 \sim 10$ & \\
\hline
\end{tabular}

（）：きわめて強い, ○：強い, 一：弱いか, もしくはない

表 3 静注用 $\beta$ 遮断薬の薬物動態の比較

\begin{tabular}{lccc}
\hline & ランジオロール & エスモロール & プロプラノロール \\
\hline 半隇期 & 4 分間 & 9 分間 & 2 時間 \\
$\beta_{1} / \beta_{2}$ & 277 & 20 & 0.6 \\
\hline
\end{tabular}

薬剤といっても過言ではないため, 「ピュア $\beta_{1}$ 遮断 薬」と名付けると，両薬㓮の違いを容易に理解する ことができる．両薬剤の最も大きな違いは心拍数の 減少効果であり, ビソプロロールのほうがカルベジ ロールに比べて圧倒的に高い.

緊急時の不整脈治療において, 静注用の $\beta$ 遮断薬 が使用される場合がある。現在，日本で使用可能な 静注用 $\beta$ 遮断薬は, ランジオロール, エスモロール, プロプラノロールの 3 剽であり，これらの薬物動態 は大きく異なる(表 3).

近年, $\beta_{1}$ 選択性が高く, 半減期が極めて短い静 注用 $\beta$ 遮断薬ランジオロールが注目されている，交 感神経活動の元進で心室頻拍や心室細動などの危険 な不整脈が頻発する病態を electrical stormとよぶ が, この electrical stormの抑制にランジオロール
が有効であることが示されている(図 7 ${ }^{10)}$. Electrical storm 時に $\beta$ 遮断薬を使用する場合, 即 効性があり, 心藏 $\left(\beta_{1}\right)$ 選択性の優れた静注薬が必 要となる. 即効性がなければ, すぐに不整脈を抑制 することができず， $\beta_{2}$ 遮断作用を有する薬郕では 気管支攣縮による呼吸不全を悪化させ，血管拡張に よる血圧低下を助長する可能性がある.これらを回 避できる薬剤がランジオロール（超短時間作用型 $\beta_{1}$ 選択的遮断薬)である. 日本循環器学会の不整脈薬 物治療に関するガイドラインにおいても, electrical stormの抑制に(静注用) III 群抗不整脈薬と並列し て, $\beta$ 遮断薬が推奨されている $(\text { 図 8 })^{11)}$. 


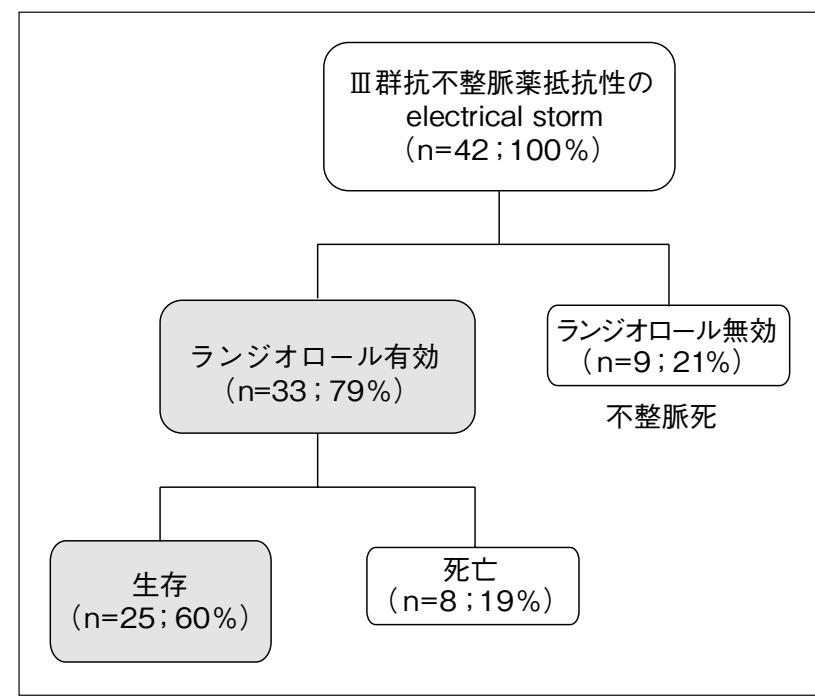

図 7

electrical stormをきたした心疾患患者に対するランジ オロールの効果を検証した臨床研究

静注用 III 群抗不整脈薬抵抗性の electrical stormに対してランジ オロールを用いると，最終的に $60 \%$ の患者を救命することが可 能であった。

〔文献 10)より引用改変〕

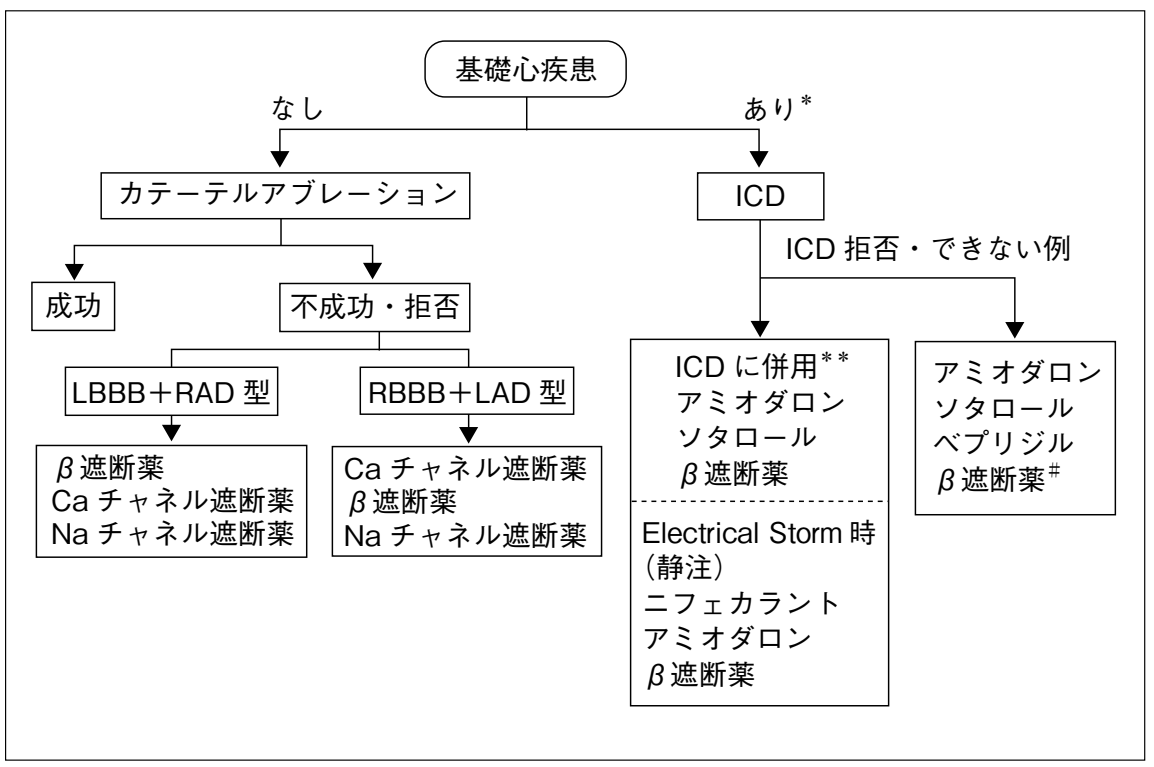

図 8

持続性心室頻拍の再発予防

* : 基礎疾患がある例でもカテーテルア ブレーションの有効例がある.

**：ソタロールまたはアミオダロン+ $\beta$ 遮断薬で作動の減少が図れる. \# : 心不全例で有用

〔文献 11)より引用〕

\section{VII. $\beta$ 遮断薬が心室不整脈の抑制に奏功した 症例の呈示}

症例は 23 歳の男性. 数力月前から通勤途中や日 中活動時に動悸を自覚するようになった，安静で消 失することから様子を見ていた，朝方，歩行中に出 現した動悸が治まらず，冷汗を伴うようになったた め，救急外来を受診した。そのときに記録された 12 誘導心電図により（図 9), 頻拍レート 184/分の 持続性心室頻拍が認められた。 左脚ブロック＋右軸
偏位型の心室頻拍であったことから, 起源は右室流 出路近傍と推察された。循環動態は保たれていたも のの, 症状が強かったことから, 静脈麻酔下で電気 的カルディオバージョンによる停止が試みられた。 頻拍は一旦停止したが，その後も心室期外収縮の頻 発, あるいは非持続性心室頻拍の出現が認められた ため, アミオダロンの点滴静注が開始された. 24 時間ホルター心電図で不整脈の出現状況を観察した ところ, 日中に持続性心室頻拍を含む心室不整脈が 頻回に出現するものの，夜間睡眠中にはほぼ消失す 


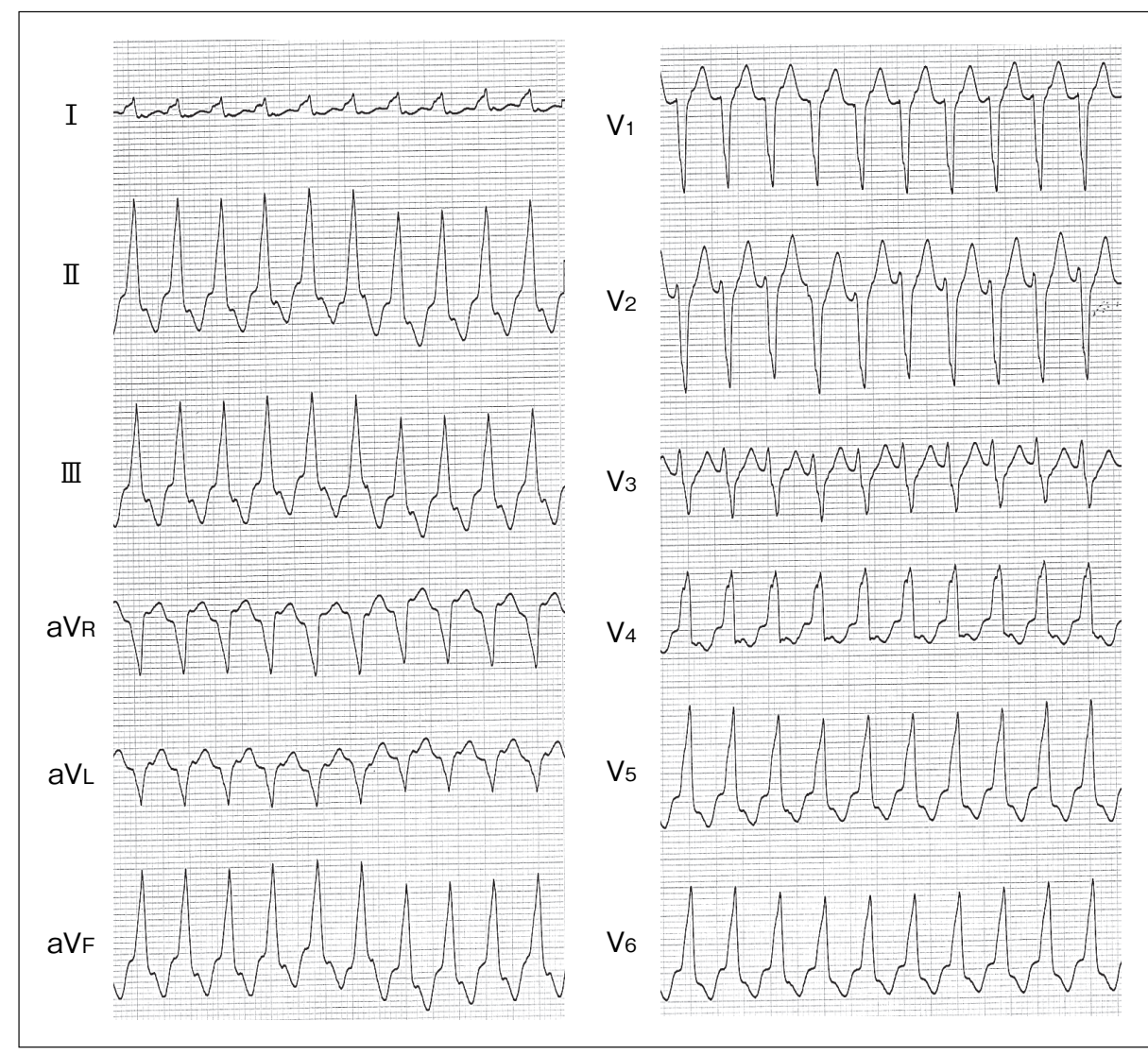

図 9

発作時の12誘導心電図記録

頻拍レート184/分の持続性心室頻 拍が記録されている.

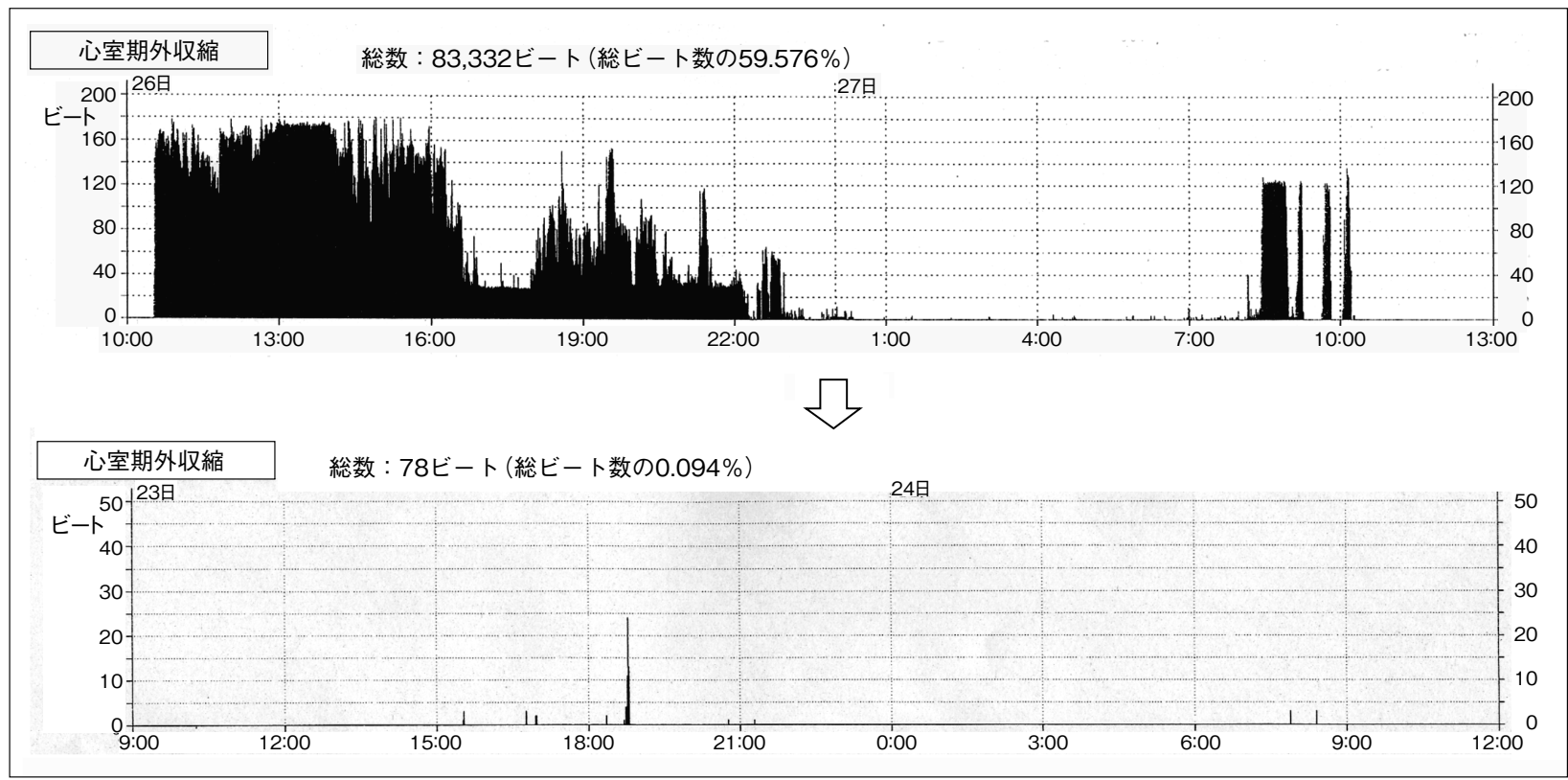

図 10 ソタロール投与前後でのホルター心電図における心室不整脈減少効果の比較

上段：投与前, 下段：投与後. 日中に頻回に出現していた心室不整脈がソタロール投与後，ほぼ完全に消失しているのがわ かる. 
ることが観察された(図 10 上段)。そのため，心室 不整脈の出現には交感神経の緊張が深く関与してい ると考えられた。 アミオダロンの点滴静注に替え て, III群抗不整脈薬で強力な $\beta$ 遮断作用を併せもつ ソタロールの経口投与を開始した $(180 \mathrm{mg} /$ 日) . そ の結果，心室不整脈は心室期外収縮を含めてほぼ完 全に消失した(図 10下段).

このように交感神経の緊張が関与する心室不整脈 には， $\beta$ 遮断薬もしくは $\beta$ 遮断作用を併せもつ抗不 整脈薬が有効であると考える.

\section{VIII.おわりに}

致死性の高い心室不整脈による心臓突然死の予防 において, ICDが有用であることはいうまでもない. しかし, ICDの補助的な治療あるいは心室不整脈(心 蔵突然死)の抑制において, 薬物治療が選択される ことも多い．交感神経活動の立進が関与する心室不 整脈の抑制には $\beta$ 遮断薬が有用であり， III群抗不整 脈薬とともに考慮されるべき薬物といえる。

\section{〔文献〕}

1) Lindemann JP, Watanabe AM : Sympathetic control of cardiac electrical activity. Cardiac electrophysiology : From cell to bedside (Zipes DP, Jalife J), Saunders, Philadelphia, $1990 ; 277 \sim 283$

2 ) Singh BN : Beta-blockers and calcium channel blockers as antiarrhythmic drugs. Cardiac electrophysiology : From cell to bedside (Zipes DP, Jalife J), 2nd ed. WB Saunders, Philadelphia, $1995 ; 1317 \sim 1330$

3 ) Priori SG, Blomström-Lundqvist C, Mazzanti A, Blom N, Borggrefe M, Camm J, Elliott PM, Fitzsimons D, Hatala R, Hindricks G, Kirchhof P, Kjeldsen K, Kuck KH, Hernandez-Madrid A, Nikolaou N, Norekvål TM, Spaulding C, Van Veldhuisen DJ : 2015 ESC Guidelines for the management of patients with ventricular arrhythmias and the prevention of sudden cardiac death : The Task Force for the Management of Patients with Ventricular Arrhythmias and the Prevention of Sudden Cardiac Death of the European Society of Cardiology (ESC) Endorsed by : Association for European Paediatric and Congenital Cardiology (AEPC) . Eur Heart J, 2015(online publication)
4 ) European Heart Rhythm Association; Heart Rhythm Society, Zipes DP, Camm AJ, Borggrefe M, Buxton AE, Chaitman B, Fromer M, Gregoratos G, Klein G, Moss AJ, Myerburg RJ, Priori SG, Quinones MA, Roden DM, Silka MJ, Tracy C, Smith SC Jr, Jacobs AK, Adams CD, Antman EM, Anderson JL, Hunt SA, Halperin JL, Nishimura R, Ornato JP, Page RL, Riegel B, Priori SG, Blanc JJ, Budaj A, Camm AJ, Dean V, Deckers JW, Despres C, Dickstein K, Lekakis J, McGregor K, Metra M, Morais J, Osterspey A, Tamargo JL, Zamorano JL ; American College of Cardiology ; American Heart Association Task Force ; European Society of Cardiology Committee for Practice Guidelines : ACC/AHA/ESC 2006 guidelines for management of patients with ventricular arrhythmias and the prevention of sudden cardiac death. J Am Coll Cardiol, 2006 ; 48 : e247 e346

5 ) Antman EM, Anbe DT, Armstrong PW, Bates ER, Green LA, Hand M, Hochman JS, Krumholz HM, Kushner FG, Lamas GA, Mullany CJ, Ornato JP, Pearle DL, Sloan MA, Smith SC Jr, Alpert JS, Anderson JL, Faxon DP, Fuster V, Gibbons RJ, Gregoratos G, Halperin JL, Hiratzka LF, Hunt SA, Jacobs AK ; American College of Cardiology ; American Heart Association Task Force on Practice Guidelines ; Canadian Cardiovascular Society : ACC/AHA guidelines for the management of patients with STelevation myocardial infarction : a report of the American College of Cardiology/American Heart Association Task Force on Practice Guidelines (Committee to Revise the 1999 Guidelines for the Management of Patients with Acute Myocardial Infarction). Circulation, $2004 ; 110: \mathrm{e} 82 \sim \mathrm{e} 292$

6 ) Olsson G, Wikstrand J, Warnold I, Manger Cats V, McBoyle D, Herlitz J, Hjalmarson A, Sonneblick EH : Metoprolol-induced reduction in postinfarction mortality : pooled results from five double-blind randomized trials. Eur Heart J, $1992 ; 13: 28 \sim 32$

7 ) Effect of metoprolol $\mathrm{CR} / \mathrm{XL}$ in chronic heart failure : Metoprolol CR/XL Randomised Intervention Trial in Congestive Heart Failure (MERIT-HF) . Lancet, 1999 ; $353: 2001 \sim 2007$

8 ) The Cardiac Insufficiency Bisoprolol Study II (CIBISII ) : a randomised trial. Lancet, $1999 ; 353: 9 \sim 13$

9 ) Connolly SJ, Dorian P, Roberts RS, Gent M, Bailin S, Fain ES, Thorpe K, Champagne J, Talajic M, Coutu B, Gronefeld GC, Hohnloser SH ; Optimal Pharmacological Therapy in Cardioverter Defibrillator Patients (OPTIC) Investigators : Comparison of beta-blockers, amiodarone plus beta-blockers, or sotalol for 
prevention of shocks from implantable cardioverter defibrillators : the OPTIC Study : a randomized trial. JAMA, $2006 ; 295: 165 \sim 171$

10) Miwa Y, Ikeda T, Mera H, Miyakoshi M, Hoshida K, Yanagisawa R, Ishiguro H, Tsukada T, Abe A, Yusu S, Yoshino $\mathrm{H}$ : Effects of landiolol, an ultra-short-acting $\beta_{1}$-selective blocker, on electrical storm refractory to class III antiarrhythmic drugs. Circ J, 2010 ; 74 : $856 \sim 863$

11) 循環器病の診断と治療に関するガイドライン $(2008$ 年度 合同研究班報告）：不整脈薬物治療に関するガイドライ ン (2009年改訂版).（http://www.j-circ.or.jp/guideline/ pdf/JCS2009_kodama_h.pdf) (2016年 2月閲覧) 